\title{
The Effects of School Feeding Programme on Enrolment and Performance of Public Elementary School Pupils in Osun State, Nigeria
}

\author{
Adekunle, D. Taylor ${ }^{1} \&$ Christiana, O. Ogbogu ${ }^{1, *}$ \\ ${ }^{1}$ Department of Public Administration, Obafemi Awolowo University, Ile-Ife, Nigeria \\ *Correspondence: Department of Public Administration, Obafemi Awolowo University, Nigeria. Tel: \\ 234-803-426-5522. E-mail: tinaogbogu@yahoo.com
}

Received: February 4, 2016

Accepted: March 24, 2016 Online Published: June 2, 2016

doi:10.5430/wje.v6n3p39

URL: http://dx.doi.org/10.5430/wje.v6n3p39

\begin{abstract}
The study assessed the School Feeding Programme of public elementary school pupils in Osun State, Nigeria. It was done with a view to determine its effects on school enrolment, retention, and academic performance of the pupils. It also elicited the challenges encountered in the implementation of the programme. The study adopted the survey research design and obtained its data from primary and secondary sources. The primary data were obtained through a structured questionnaire administered on 116 respondents in 10 randomly selected public elementary schools in Osun State. The questionnaire was complemented by in-depth interview of 23 purposively selected officers involved in the implementation and monitoring of the school feeding programme. The retrieved data were analysed using descriptive statistics. The results showed that pupils are fed daily through the school feeding programme (87\%), which is funded through cost sharing between the State and local governments (78\%). It was also found that the school feeding programme in Osun State has resulted in an increase in pupils' enrolment (78.4\%), retention (44.8\%), as well as regularity (58.6\%) and punctuality (69\%) in school attendance. It has also enhanced the pupils' performance in curricular and extracurricular activities (55.2\%). The major challenges were found to be insufficient funding (62.2\%), insufficient classrooms and furniture to cope with increase in enrolment (60.86\%), heavy workload for teachers (60.86\%) and lack of effective monitoring and evaluation system (60.86\%).The study concluded that the School Feeding Programme in Osun State has increased the enrolment and improved the performance of elementary school pupils in the state.
\end{abstract}

Keywords: public elementary school; school feeding programme; enrolment; performance; Osun state; Nigeria

\section{Introduction}

School feeding programmes constitute critical interventions that have been introduced in many developed and developing countries of the world to address the issue of poverty, stimulate school enrolment and enhance pupils' performance. In developing countries, almost 60million children go to school hungry everyday and about 40 percent of them are from Africa. Providing school meals is therefore vital in nourishing children. Parents are motivated to send their children to school instead of keeping them at home to work or care for siblings (Akanbi, 2013).The introduction of the school feeding is traced to the Millennium Development Goals (MDGs) initiative and several conferences held thereafter by African leaders which aimed to tackle issues, such as peace, security, good economic, political and corporate governance and to make the continent an attractive destination for foreign investment. Some of these developments include the 'New Partnership for African Development' which according to the blueprint is a pledge by African leaders, based on common vision and a firm and shared conviction, to eradicate poverty and to place their countries on the path of sustainable growth and development and, at the same time, to participate actively in the world economy and politics. Also, the 'Comprehensive African Agriculture Development Programme' and the 'Millennium Hunger Task Force' amongst others were initiatives which were designed to link school feeding to agricultural development through the purchase and use of locally produced food (Bundy et al, 2009).

Nigeria happened to be one of twelve (12) pilot countries invited to implement the programme. So far, Nigeria, Cote d'ivore, Ghana, Kenya and Mali commenced the implementation of the school feeding programme. As a result, the Federal Government came up with the Universal Basic Education Act in 2004, which provided the enabling 
legislative backing for the execution of the Home Grown School Feeding and Health Programme. Towards the realization of the objectives of the Universal Basic Education programme and the central role of nutrition, the Federal Ministry of Education launched the Home Grown School Feeding and Health Programme in 2005. The overall goal of the School Feeding Programme in Nigeria is to reduce hunger and malnutrition among school children and enhance the achievement of Universal Basic Education. Osun was among the twelve (12) States selected to begin a phased-pilot roll out implementation of the programme. Although The Home Grown School Feeding and Health Programme was launched, it did not receive attention until the change of government in the State in November, 2010. Subsequently, the new administration, under the leadership of Ogbeni Rauf Aregbesola convened an education summit headed by Professor Wole Soyinka. The summit's objective was to critically examine the problems hampering growth and progress of education in the State and to proffer workable solutions. At the end of the Summit, recommendations were made towards repositioning education in Osun State which among others included the School Feeding Programme transformation. Thereafter, a comprehensive review of the old school feeding programme was undertaken. The Programme was re-packaged and christened "Osun Elementary School Feeding and Health Programme - O' meals" It was formally launched in the State on $30^{\text {th }}$ April, 2012 with the pupils in Grades 1-3 of the Public Primary Schools in the State being fed with one meal per day(Ministry of Education,2014).

Literature abound on the benefits of School Feeding Programme to pupils but not much has been done to highlight the impact of the programme on school enrolment, retention and pupils' academic performance. This study therefore seeks to fill the gap by assessing School Feeding Programme as it is being implemented in Public Elementary schools in Osogbo, Osun State, Nigeria.

\section{Literature Review}

\subsection{The Concept and Origin of School Feeding Programme}

School feeding is simply the provision of food to children through schools. According to Oyefade (2014), different countries have one or a combination of the two feeding modalities in place for various objectives. However, they can be grouped into two broad categories: in-school meals and take-home rations where families are given food if their children attend school. Historically, in-school meals have been the most popular modality of school feeding interventions. The school feeding can be in turn grouped into two common categories: programme that provides meals and programme that provides high-energy biscuits or snacks to generate greater impacts on school enrolment, retention rates, and reduce gender or social gaps (Akanbi, 2013). Uduku, (2011) contended that there are 'indications of a significant swing in thinking about school feeding and many elements of this new thinking are being promoted keenly under the rubric of "home grown school feeding".

Tomlinson (2007) traced the emergence of school feeding programme to the 1930s in the United Kingdom and the United States of America with a focus on improving the growth of children. In 1900 Netherlands became the first country to move the programme to a new level of incorporating school meals into a national legislation. By the 1930s, the United Kingdom and the United States had also instituted the school feeding programme as part of their national programmes. A further account indicates that school feeding initiatives have been in existence since the late 1700's and originated as projects of donors in Europe. The United States of America began the practice of initiating school feeding programmes in Austria as an act of international aid focused on combating the severe malnutrition of children in the 1940s after the Second World War. Since then, school feeding programmes have become a key part of food assistance, relief emergency and development programmes. School Feeding Programme is a social safety net for children and as part of the national development goals. It provides an important new opportunity to assist poor families and feed hungry children. It provides incentive for poor families to send their children to school and keep them there.

In order to improve the nutritional status of school children, the Federal Government of Nigeria launched the Home-Grown School Feeding and Health Programme in September, 2005 under the coordination of the Federal Ministry of Education. The programme aimed to provide pupils with adequate meal during the school day (FME, 2007). The scheme, officially known as Home Grown School Feeding Programme insisted on buying the foodstuffs from the local farmers. It therefore reduced the rate of malnutrition while it also provided the local farmers the opportunity to sell their produce to participating schools. According to the Federal Government's directive, Federal, State and Local Governments were to fund the programme with the State and Local Governments providing the bulk. 


\subsection{The Content and Administration of the School Feeding Programme in Osun State, Nigeria}

The menu for the school feeding programme is based on national guidelines but adjusted to accommodate local availability. The school meal served is assorted and nutritious and the programme is coordinated by a chief executive officer in a secretariat in the Osun state deputy governor's office as well as the commissioner for education. For the effective and efficient programme implementation, food vendors were appointed, trained and equipped with uniforms and working materials. In addition a monitoring and evaluation committee was constituted and headed by the director of the inspectorate services in the ministry of education. Also, the local inspectors of education and zonal inspectors of education are members of the steering committees who supervise the programme. The state Ministry of Education, the State Universal Basic Education Board and Ministry of Health collect data on general child health. The Local Government Education Authorities which are field offices of the State Universal Basic Education Board, Head teachers, Teachers, Teachers’ Associations, are also involved in the administration of the programme.

The programme is linked to agriculture with the aim of boosting food production and sales as well as providing employment for the people in the neighborhood of local areas that form catchment areas for the Elementary Schools. The community food vendors are fully integrated into the well-structured supply chain through which local farmers provide them with the necessary food materials required for the meals. This does not only ensure cost-effectiveness, but ensures that the money expended sinks back into the State's economy and generates maximum multiplier effects on the people (Yunusa et al, 2012).

The school feeding programme secretariat ensures that the food vendors are paid fortnightly in advance directly into their accounts as well as monthly transport subsidy. The vendors do not cook in schools however a nutritious and balanced diet is given to pupils.

The strategic and technical partners for the programme include the Partnership for Child Development, based in Imperial College, United Kingdom and the Sahara Group / Food Basket Foundation International. The School feeding programme relies on continuous support and goodwill of these stakeholders. Innovative ways of funding, such as communities, philanthropists and non-governmental organizations fill up the funding gaps (Oyeniran, 2014).At a meeting held on Home Grown School Feeding Programme on 19 ${ }^{\text {th }}$ May, 2014 in Abuja and a Technical Meeting on Osun school feeding programme held from $21^{\text {st }}-23^{\text {rd }}$ May, 2014 in Osogbo, the programme was reviewed and Osun state school feeding programme was adjudged one of the best practices in the country's education sector. The meeting which was organized by the Federal Government of Nigeria and Osun State with the support from the Partnership for Child Development (PCD), World Bank and Vitol Foundation was aimed at advancing the school feeding programme and to address the policy and legal framework, institutional capacity and stable funding. A communiqué was issued at the end of the Round Table which among others contained recommendations for the institutionalization, proper funding and replication of Osun and Kano school feeding models in all the States of the federation (PCD, 2014).

\subsection{The Effect of School Feeding Programmme on School Enrolment and Retention}

As observed by Oyefade, (2014), the decision to enroll a child in school and, thereafter, for the child to attend regularly is influenced by many factors. These include the perceived value of education, the availability of employment opportunities, the direct and indirect cost of schooling and the availability and quality of school facilities. Food incentives offered to students such as school meals compensate parents for direct educational costs. He observed further that implementation of SFP is associated with increase in enrolment, particularly for girls.

Also, several studies have found a strong relationship between education and poverty, particularly inequality. The poor are heavily deprived and so are their children. As observed by Oyefade (2014), several factors with significant impact on many dimensions of poverty on school attendance and education quality, particularly early childhood malnutrition, deprivation based on gender and income inequality tend to be responsible. In many countries, such as Brazil, Philippines, Cambodia, Mali, El Salvador, Indonesia, Ghana, Bangladesh, Ecuador etc where school feeding programmes are implemented, data reveals that the programme has increased enrolment and attendance rates over the years (Akanbi 2013).

In Bangladesh, the research carried out by The International Food Policy Research Institute on the effects of school feeding programme found that the programme raised school enrolment rates by $14.2 \%$, reduced the probability of dropping out of school by $7.5 \%$ and increased school attendance by 1.3 days a month. Similarly, in Pakistan a programme provides an income in the form of one or two tins of oil to families whose girls attend school for twenty days per month. In its pilot phase, the oil incentive programme demonstrated that it could make a significant contribution to full attendance. In participating schools, enrolment improved overall while attendance increased from $73 \%$ to $95 \%$ among participants. The programme also claims to put additional food in the hands of mothers to serve 
as a contact between mothers and teachers on distribution days. In another study in Bangladesh, a programme of school-based food distribution increased enrolment by $20 \%$ and a $2 \%$ decline in non-participating schools (Ahmed, 2004).

Still on the issue of SFP and enrolment, Oyeniran (2014) observed that schooling and institutions regulating access to enrolment in developing countries, to some extent, contribute to the class and social divide in urban areas. Equally, educational opportunity is driven by unequal and asymmetric political decision-making structures whereby people from poorer backgrounds tend to bear the brunt of national and local policies. He contended that availability of schools does not automatically result in higher enrolment numbers and submitted that some families cannot send their children to school because the combined cost of fees, textbooks and uniforms is prohibitive.

However, studies have further revealed that provision of food must not be the only focal-point for improving access to education or education opportunity equality. Poor education environment can contribute to drop out rate, while quality education increases enrolment which can lead to classroom overcrowding. Psacharopouls (1998) indicated that the quantified benefits of investing in education are highest at primary levels. This view provides a strong case for expanding investment in primary rather than higher levels of education. Public interest in School Feeding Programmes have stemmed from the endorsement of the view that education is essential in the promotion of the quality of human life for economic and social development. Education has for many years served as a vehicle for empowering and transforming people for better societies and the world as a whole.

In the last few years, SFPs have enjoyed massive support and attention from international organizations and many development partners, this can be attributed to the multi-faceted role of this social intervention (education, health, agriculture) in achieving development objectives in many countries and a 'perceived' demand for the programme. In its multi-faceted role, SFPs can be linked to several of the MDGs namely; eradication of extreme poverty, hunger, achieving universal basic education, promoting gender equality and women empowerment, developing a global partnership for development, hence, the use of SFPs in the developing countries is a significant intervention to be considered (Birdsall et al, 2005)

\subsection{The Effects of School Feeding Programme on Pupils Academic Performance}

Many studies on nutrition have shown that under nutrition in children stunts their growth and mental development, hence, the relationship between nutrition and academic performance (Alabi, 2003). Although, food has classically been perceived as a means of providing energy and building materials to the body, research over the years has provided exciting evidence for the influence of dietary factors on mental function. Not only are children motivated to get into school but also there is a significant impact on their nutritional status and development, cognitive capabilities and academic performance. Literature has shown that the development and learning potential of the beneficiaries depend on the quality and nutrient components of food (Jukes et al, 2008).

Nutritional and health status are powerful influences on a child's learning and how a child performs in school. Children who lack certain nutrients in their diet do not have the same potential for learning as healthy and well nourished children. Children with cognitive and sensory impairments naturally perform less and are more likely to repeat grades. The irregular school attendance of malnourished and unhealthy children is one of the key factors for poor performance (Uduku, 2011).

Yunusa (2012) noted that students in School Feeding Programmes have the potential for improving their performance because it enabled them attend school regularly and studied more effectively. He found that in a study carried out in Jamaica, children in Grade 2 scored higher in Arithmetic when they started being fed at school. However, the impact of School Feeding Programme on the academic performance of pupils has been embraced with mixed feelings. It was observed that although SFPs motivate parents to enroll their children in school, its impact on academic performance is mixed and depends on various factors within the context in which the programme is set. Drawing from this, Uduku (2011) opined that SFPs would best improve the performance of pupils when coupled with adequate learning materials, physical facilities and teacher motivation.

\section{Method}

The study adopted the survey research design and obtained its data from both primary and secondary sources. The primary data were obtained through structured questionnaire administered on 116 respondents in 10 public elementary schools in Osogbo using the random sampling technic. The administration of questionnaire was supplemented by in-depth interview of 23 purposively selected officers in elementary schools and the Local Government Education Authority involved in the implementation of the programme in Osogbo local government 
area of Osun State, Nigeria. Secondary data were sourced from relevant records and documents from the sampled schools to complement the primary data. The retrieved data were analysed using simple descriptive statistics in the form of simple percentages and reported using the triangulatory process.

\section{Results and Discussion}

Results of the interviews conducted as well as those generated from the questionnaire are presented in the tables below:

Table 1. Respondents’ Assessment of the Osun State School Feeding Programme

\begin{tabular}{ll}
\hline $\begin{array}{l}\text { Responses } \\
\text { Meals are provided for the pupils daily and promptly while in school. }\end{array}$ & $\begin{array}{l}\text { Frequency } \\
20(87) \\
\text { The government formulates the policy objectives and monitors the } \\
\text { implementation of the school feeding programme. } \\
\text { The SFP is funded through cost sharing between the state and local } \\
\text { governments. }\end{array}$ \\
$\begin{array}{l}\text { There is policy guideline to ensure the sustainability of the programme. } \\
\text { The programme enjoys support from international organizations. }\end{array}$ & $18(78)$ \\
$\begin{array}{l}\text { The meals served are assorted and nutritious such as yam, cocoyam porridge, } \\
\text { rice, beans porridge, bread, vegetables, eggs, beef, fruits, chicken, egusi } \\
\text { garnished with vegetables }\end{array}$ & $13(56 \%)$ \\
\end{tabular}

Table 1 presents the results of the interviews conducted with the 23 officers involved in implementing and facilitating the school feeding programme. Majority (87\%) of the respondents indicated that mid-day meals are served daily and that all the schools where the programme is being implemented use the same timetable approved by the programme secretariat. A sizeable number (65\%) of the respondents indicated that the government formulates the policy objectives and monitors the programme implementation. The interview with one of the officers revealed that the school feeding was initially a federal government programme but was implemented in the State under the rubric of Home Grown School Feeding and Health Programme with appropriate funding support. The programme has however been re-packaged and is currently being funded by the state and local governments through cost sharing. This is evident from the results on the table as $78 \%$ of the respondents indicated that the programme is funded through cost-sharing between the state and local governments; this lends credence to this assertion.

Data on the table further shows that $65.2 \%$ of the respondents indicated that there is policy guideline to ensure the sustainability of the programme. This is imperative, not only to ensure sustainability, but also uniformity in programme implementation in terms of the content (menu), timing for school meals, hygiene, food preparation e.t.c. The interview revealed that the government plans to extend the programme to the Middle School level because of its educational benefits. Result on the table further shows that $56 \%$ of the respondents indicated that the SFP enjoys support from international organizations. From investigation, it was found that Partnership for Child Development (PCD), based in Imperial College, U.K has been supporting the State Government in implementing the School Feeding Programme, especially in the area of capacity building, programme review and putting in place effective monitoring and evaluation system. As reported in the programme's manual, the programme gulps 3billion Naira annually and in consideration of its expensive nature and the success of the programme, the state government has sought the partnerships of organizations, such as Partnership for Child Development, in the United Kingdom and the Sahara Group / Food Basket Foundation International.

Data on the table further indicates that $78 \%$ of the respondents interviewed affirmed that the pupils are fed with assorted and nutritious meals in accordance with the programme content. The interview with the respondents further revealed that the menu is based on the state government's guidelines to accommodate seasonal needs and local availability. The sampled schools complied with the menu time (mid-day) and menu standard table. 
Table 2. Respondents' Opinions on the Effects of School Feeding on Pupils' Enrolment and Retention

\begin{tabular}{llllllll}
\hline Responses & SA & A & U & SD & D & MEAN & RANK \\
\hline $\begin{array}{l}\text { There is an increase in school } \\
\text { enrolment due to the provision } \\
\text { of school meals }\end{array}$ & $91(78.4)$ & $24(20.7)$ & $1(0.9)$ & - & - & 4.76 & 1 \\
$\begin{array}{l}\text { School feeding encourages } \\
\text { punctuality }\end{array}$ & $80(69.0)$ & $33(28.4)$ & $2(1.7)$ & $1(0.9)$ & - & 4.62 & 2 \\
$\begin{array}{l}\text { It has contributed to students' } \\
\text { regular attendance of school }\end{array}$ & $68(58.6)$ & $45(38.8)$ & $1(0.9)$ & $2(1.7)$ & - & 4.53 & 3 \\
$\begin{array}{l}\text { There is an increase in pupils } \\
\text { retention in school because of } \\
\text { provision of meals }\end{array}$ & $52(44.8)$ & $61(52.6)$ & - & - & $3(2.6)$ & 4.42 & 4 \\
$\begin{array}{l}\text { It has reduced the dropout rate } \\
\text { of pupils }\end{array}$ & $60(51.7)$ & $37(31.9)$ & $2(1.7)$ & $4(3.4)$ & $13(11.2)$ & 4.28 & 5 \\
\hline
\end{tabular}

Results in Table 2 show that there has been a steady increase in pupils' enrolment as a result of the school meals; this is because majority of the respondents (78.4\%) strongly agreed with this opinion and it ranked $1^{\text {st }}$ with a mean score of 4.76. Ranking $2^{\text {nd }}$ was the fact that the feeding programme encourages punctuality of pupils in school. The table shows that $69 \%$ of the respondents strongly agreed with this assertion. Also, $58.6 \%$ of the respondents indicated that the feeding programme has encouraged regular pupils' attendance in schools. Moreover, $44.8 \%$ of the respondents strongly agreed that there was an improvement in pupils' retention in school, with a mean score of 4.42 and ranking $4^{\text {th }}$. The drop-out rate, due largely to some constraints, such as poverty has reduced drastically as $51.7 \%$ of the respondents supported this view.

Results of the interview conducted with some of the Head teachers corroborated this view. For instance, one of the Head teachers commented thus:

'There has been a steady increase in enrolment and school attendance is regular. Even if pupils are sick, they like to come back to school to collect their meals'

It could be inferred that the programme has activated people's confidence in the public elementary school system again. This is because in 2011, very low pupils' enrolment was recorded partly due to poor implementation under the preceding administration. The enrolment increased steadily thereafter as a result of the programme's repackaging and re-invigoration by the administration of Aregbesola. The Head teachers and teachers interviewed affirmed that the operation of the programme has resulted in an increase in pupils' enrolment as well as regular and punctual school attendance. They noted that truancy and absenteeism have drastically reduced since the pupils' are sure of being provided with free meals in school. Furthermore, improved pupils' enrolment, attendance and retention were attributed to some other factors, such as provision of free textbooks and free uniforms for pupils, well motivated teachers and improved teaching-learning environment.

Table 3. Respondents' Opinions on the Effects of School Feeding on Pupils' Academic Performance

\begin{tabular}{|c|c|c|c|c|c|c|c|}
\hline Response & SA & $\overline{\mathbf{A}}$ & $\overline{\mathbf{U}}$ & SD & $\bar{D}$ & MEAN & RANK \\
\hline $\begin{array}{l}\text { There is improvement in pupils' } \\
\text { performance in both curricular } \\
\text { and extra curricular activities }\end{array}$ & $51(44)$ & $64(55.2)$ & $1(0.9)$ & - & - & 4.41 & 1 \\
\hline $\begin{array}{l}\text { Pupils' performance in end of } \\
\text { term and session exams has } \\
\text { improved. }\end{array}$ & $51(44)$ & $56(48.3)$ & $1(0.9)$ & - & 8(6.9) & 4.37 & 2 \\
\hline $\begin{array}{l}\text { Pupils' performance in class } \\
\text { tests has improved. }\end{array}$ & $56(48.3)$ & $49(42.2)$ & $1(0.90$ & - & $10(8.6)$ & 4.34 & 3 \\
\hline $\begin{array}{l}\text { Pupils' performance in class } \\
\text { tests/ exams have nothing to do } \\
\text { with school feeding }\end{array}$ & $2(1.7)$ & $20(17.2)$ & $1(0.9)$ & $48(41.4)$ & $45(38.8)$ & 2.78 & 4 \\
\hline
\end{tabular}


Table 3 presents the respondents opinions on the effects of school feeding on pupils' academic performance. The table shows that $44 \%$ of the respondents strongly agreed that there is improvement in the performance of pupils' both in curricular and extra-curricular activities; this ranked $1^{\text {st }}$ with a mean score of 4.41 . In the same vein $44 \%$ of the respondents also affirmed that there is an improvement in the performance of pupils' in the examinations held at the end of each term and session; this ranked $2^{\text {nd }}$ with a mean score of 4.37 . Data on the table further shows that $48.3 \%$ of the respondents indicated that the performance of pupils in class tests had improved as a result of the school feeding programme. In support of the results on this table, the Head-teachers and teachers interviewed revealed that pupils' performance in class tests and all examinations had improved remarkably due to meals served to pupils. Result on the table further shows that an insignificant number $(1.7 \%)$ of the respondents strongly agreed that the pupils' performance in class tests and exams has nothing to do with the school feeding programme.It is however important to know that the effect of school feeding cannot be the same on pupils across the elementary schools in Osun state in absolute terms and this explains why the pupils' performance in central examinations such as the State Joint Elementary School Examination varies from one school to the other. In view of this, Oyeniran (2014) noted that the effect of school feeding on performance also depends on other factors such as adequate learning materials, physical facilities and teacher motivation, to mention a few.

Table 4. Respondents' Opinions on the Challenges of the School Feeding Programme

\begin{tabular}{ll}
\hline RESPONSES & FREQUENCY (\%) \\
Absence of a legal frame work and policy to support the SFP & $06(26.8)$ \\
Insufficient funding & $15(62.2)$ \\
Overcrowded classrooms & $12(52.2)$ \\
Insufficient classrooms and furniture to cope with increased enrolment & $14(60.86)$ \\
Heavy workload for teachers & $14(60.86)$ \\
Inability to effectively monitor the food preparation to ascertain the & $13(56.52)$ \\
quality of food and the environment & $12(52.2)$ \\
Food is prepared outside the school premises by vendors & $10(43.5)$ \\
There is no central place for the pupils to take their meals & $12(52.2)$ \\
Pupils have no access to good source of water after meals & $14(60.86)$ \\
Lack of effective monitoring and evaluation system & $13(56.52)$ \\
Quantity of food served is small &
\end{tabular}

Table 4 presents the results of the interview held with the facilitators of the school feeding programme to find out the challenges facing its implementation in the sampled schools. Data on the table shows that very few (26.8\%) of the respondents indicated that an absence of a legal framework and policy to back up the programme was a challenge. The response from the State programme officer interviewed revealed that efforts were being made by the Osun state government to back the programme up with appropriate legislation in order to enhance it and ensure its sustainability.

Data on the table shows that majority (62.2\%) of the respondents indicated that insufficient funding was identified as another challenge facing the programme implementation. This also accounts for the reason why there are insufficient classrooms and furniture to cope with the increase in enrolment (62.86\%). One of the Head teachers interviewed noted that sometimes some pupils have to share desks and chairs with their mates while some others sit on the floor or stand up while lessons are on. The interviewees also noted that there was a mismatch between increased enrolment and provision of infrastructure and learning materials. They emphasized that there had been an influx of pupils from the private schools to public schools due to free school meals and free textbooks. They confirmed this development and stated further that there is a subsisting Government directive that the schools should not shut their gates against the in-coming pupils willing to benefit from free elementary education and the school feeding programme. The Programme Officer specifically reiterated that funding was a major challenge and noted that the programme is expensive. She disclosed that the state government was making efforts to explore opportunities of donors' support from UNICEF, Partnership for Child Development (PCD), Vitol Foundation, Sahara Group, Bill and Milinda Gates Foundation as well as the Global Child Nutrition Foundation. She submitted that the impact of the aforementioned 
had been felt more in capacity building and cited the round table meeting of stakeholders of the school feeding programme held in May, 2014 in Abuja and Osogbo respectively which were jointly organized by Partnership for Child Development and Vitol Foundation, in collaboration with the federal government and Osun state government

Results on the table further shows that overcrowded classrooms was also identified by majority (52.2\%) of the respondents as a challenge, considering the UNESCO standard of teacher - pupil ratio of 1-40 in elementary schools. Also, $60.86 \%$ of the respondents indicated that heavy work load for the teacher was another challenge. It was observed that even though there were teachers in the sampled schools, the number of pupils was rather too high (off the UNESCO standard of ratio 1-40). This perhaps explains why the teacher confirmed that regular tests were not administered on the pupils as expected.

Majority (56.52\%) of the respondents indicated that inability to monitor the food preparation to ascertain its quality and that of the environment posed a major challenge. Also, 43.5\% of them indicated that the absence of a central place (Dining Hall) in the school where the pupils' could eat their meals constituted a challenge. It was observed that the preparation of the meals was contracted out to food vendors who cooked the food in their respect homes and then transported them to the various schools. One of the Head teachers disclosed during the interview that it was practically not easy to assess the sanitary condition of the place where the food was prepared. However, further investigation revealed that a monitoring committee had been established by the programme secretariat to supervise the food preparation. In addition to this arrangement it was revealed that each school had a health teacher whose duty it is to supervise the meals brought by the food vendors to ensure that they are of good quality before pupils are served. The arrangement of food preparation outside the school premises has been identified at the round table meeting of the stakeholders of the programme held in May, 2014 in Abuja and Osogbo as one of the gaps in the programme implementation which needs to be revisited.

Furthermore, $52.2 \%$ of the respondents indicated that pupils from the benefiting schools have no access to good source of potable water after taking their meals. Thus most of the students brought drinking water from their respective homes. It was however noted during the visit to the schools that some of them have potable drinking water while some didn't have. Further investigation revealed that the state government through the Rural Water, Environmental and Sanitation Agency had commenced the sinking of boreholes in all the schools. In addition to this, it was found that some communities also complement the efforts of the government by sinking wells for their schools.

The importance of monitoring and evaluation system in implementation of programmes cannot be underestimated, in view of this $60.86 \%$ of the respondents noted that lack of adequate evaluation and monitoring mechanism is a major challenge of the programme. Some of the interviewees however, noted that there exists some form of monitoring systems at the state and school levels. At the state level, the state monitoring committee and state steering committee responsible for programme oversight, the state ministry of education and the state universal basic education board are responsible for collecting data on school enrolment and attendance on regular basis; the ministry of health is responsible for collecting state-wide data on general child health and nutritional status; Local government education authority secretaries and planning officers are responsible for collecting weekly feeding forms that consist of the number of pupils that have been fed and for collating the data for the programme and the zonal inspectors of education are responsible for monitoring the feeding process, environmental health and enrolment data. At the school level, the school-based monitoring committees are responsible for the programme oversight; the quality of the food is monitored by the head teacher or health teacher while the Parents' Teachers' Associations' representative and the school prefects randomly inspect the food. Surprise checks are also conducted regularly by programme monitors. These monitoring systems are challenged by lack of funds, vehicles and growth monitoring gadgets required for effective programme planning, review and improvement. Generally, results on the table 4 shows that which the government needs to address to ensure that its laudable objectives are achieved and sustained.

\section{Conclusion}

This study has revealed that School Feeding Programme is a critical intervention which has tremendous education benefits. It has improved the enrolment and performance of elementary school pupils in Osogbo local government area of Osun State Nigeria, as well as enhanced their retention. This study also found that School Feeding Programme enhanced performance and encouraged the completion of basic education. It was however found that School Feeding was not a novel idea in Nigeria. This is because The Basic Education Commission (UBE) Act of 2004 made provision for at least, a meal for pupils every school day, but there has not been demonstrable political will by successive administration in the country to actualize this. It is only Osun and Kano States that have taken the 
gauntlet to revive the programme. Over the years, World Food Programme has shown keen interest in School Feeding Programmes across countries of the world and suggested standards to guide the design and implementation of sustainable school meals programme. These include: a strategy of sustainability, a national legislation/ policy framework, stable funding and budgeting, an institutional arrangement for implementation, monitoring and accountability etc. Unfortunately, this study found that the implementation of the School Feeding Programme falls short of some of the standards stipulated by the World Food Programme due to various challenges. The study concluded that the state government should double its efforts to address the gaps identified in the programme implementation in order to sustain the impressive pupils' enrolment and performance. In order to foster this, the study suggested the need for sustainable funding to be solicited from all stakeholders, corporate bodies and multi-national companies. To complement the existing legislation, it is suggested that a national policy framework be put in place to guide programme implementation. In view of the capital intensive nature of School Feeding Programme and the dwindling state revenue, further research needs to be carried out on funding sources and the implications on the nutritional values of the approved menu for the programme.

\section{References}

Ahmed, A. U. (2004). Food-for-Education Programme with Locally Produced Food: Effects on Farmers and Consumers in Sub-Sahara Africa. Washington D.C: International Research Food Policy Institute.

Akanbi G.O. (2013). Home Grown School Feeding and Health Programme in Nigeria: An Innovative Approach to Boosting Enrolment in Public Primary Schools - A Study of Osun State, 2002-2010. African Symposium, 11(2), 8-12.

Alabi A.T. (2003). Evaluation of the Impact of Universal Basic Education Process on Primary School Enrolment in Kwara State. Nigerian Journal of Educational Research and Education, 4(1), 12-13.

Birdsall, L.R., Levine, A., \& Ibrahim, A. (2006). Towards Universal basic Education: Investments, Incentives and $\begin{array}{lllll}\text { Institutions. } & \text { European }\end{array}$ http://dx.doi.org/10.1111/j.1465-3435.2005.00230.x

Bundy, D., Burbano, C., Grosh, M., Gelli, A. M., Jukes, C.H., \& Drake, L.J. (2009). Rethinking School Feeding: Social Safety Nets, Child Development, and the Education Sector. The World Food Programme and the World Bank, Washington, DC. http://dx.doi.org/10.1596/978-0-8213-7974-5

Federal Ministry of Education (2007). National Guidelines for School Meals Planning and Implementation. Abuja, Nigeria.

Jukes M.C.H., Drake L.J., \& Bundy D.A.P. (2008). School Health Nutrition and Education for All: Leveling the Playing Field. Cambridge: CAB Publishers.

Osun State Ministry of Education (2014). Osun Elementary School Feeding \& Health Programme. O’ meals Manual Osun State Government.

Oyefade S.A. (2014). Administration of Home Grown School Feeding \& Health Programme in Osun State. Unpublished MPA Long essay, Department of Public Administration, Faculty of Administration, Obafemi Awolowo University, Ile-Ife.

Oyeniran, O.B. (2014). Rich Country Poor People: Nigeria's Poverty in the Midst of Plenty. Manchester, U.K: Technopol Publishers.

Partnership for Child Development. (2014). Osun State Home Grown School Feeding Programme: Improving Sustainability through Increased Local Farmer Participation. HGSF Working Papers Series No.12.

Psacharopouls, G. (1998). Education and Development: A Review. World Bank Research Observer, 3(1), 99-116. http://dx.doi.org/10.1093/wbro/3.1.99

Tomlinson, M. (2007). School Feeding in East and Southern Africa: Improving Food Sovereignty or Photo Opportunity? Equity Discuss Paper, N0. 46.

Uduku. (2011). School Building Design for Feeding Programme and Community Outreach: Insights from Ghana and South Africa. International Journal of Educational Development, 31, 59-66. http://dx.doi.org/10.1016/j.ijedudev.2010.06.005

Yunusa, I., Gumel, A.M., Adegbusi, K., \& Adegbusi, S. (2012). School Feeding Programme in Nigeria: A Vehicle for Nourishment of Pupils. The African Journal, 12(2), 53-67. 